\title{
The impact of creative abilities and the organizational context of managers on the developing content of the travel agencies in Egypt
}

\section{introduction:-}

\section{Dr. Nadia Houssain Maher}

The study aims at building a theoretical model, which describes the elements and effects of developing processes in tourist companies as well as testing it practically upon a sample of companies.

The study has depended on a sample of tourist companies category (A) and (B), consisting of (52) tourist companies. The study used the simple declining styles and the multi declining and the choices ( $\mathrm{T}-$ test) with the aim of testing the study hypotheses.

One of the most important things the study has come to is the impulsive relation between the creative abilities of managers and practicing organizational development.

Besides having no relation between creative abilities of mangers and the content of organizational development, in addition the study has also found that the disorder in the organizational structure was the only element motivating organizational development at the company level as a whole and on the work group as well.

Also the existence of negative psycho attitudes for workers in the company. This was one of the most important changes of the organizational style which led to developing companies such as reconstructing, changing communications styles and reaction in the company. Lately the study has proved that there is a rise in creative abilities in tourist companies' category (A) in the tourist companies. 
In addition, there has been a noticeable improvement in the quality of three elements for organizational style: Aims, incentives and decisions making in companies category (A) compared with category (B)

Organizational change \& Development

Recently researchers are increasingly interested in the subject. Scientific conferences and debates have been held locally and worldwide.

It is noted that researches and studies in the field of organizational change and development have concentrated greatly on this institutional aspect of the change process.

There is an interest in describing the range of the organization to develop itself and the response to changes in the external environment where it works. Most researching efforts have concentrated in this field on the following:

(1) Discovering the causes and motives of organizational change.

(2) Knowing how institutions respond to change in external environment.

(3) The range of resistance or acceptance which the trials of development face in organizations.

(4) Describing the stages of organization change process.

(5) Clarifying how the organizational change leads to finding new organizational shapes as a response to changes in the external environment of organizations.

The researchers think that the conductive aspect and the creative characteristics of managers are not less important than the institutional aspect in limiting the level, the content and the results of the change process in organizations. Besides, the effect of organizational context or the inner environment dominating in organizations is not less important than the role of the external environment and the conditions of market and the competition in 
starting and orientating the change process and developing organizations. (Kotter 1994; 1996) has delivered a list with the causes of failure attempts for organization (change in western organizations). These causes are due to mistakes committed by managers during starting and leading the change process in their organizations.

For the importance of the organizational context changes in describing and explaining the change process (Damanpour, 1991) presented a study stating meta-analysis for the outcomes of research and former studies in the field of change. He reached the importance of organizational change context in explaining the range of success or failure of change efforts the organizations do. In addition the study of (Sastry, 1997) explaining the mechanisms of change has resulted in stating probabilities of success or failure in four items:

(1) Strategic directing of management.

(2) The degree of organizational stagnation.

(3) The range of realizing the supreme management regarding the quality of the organization performance.

(4) The existence of external and internal stresses hoping for change.

Results of these studies render a strong practical evidence concerning the importance of taking the change context into consideration when describing and explaining the changes processes in contemporary organizations.

So the current study seeks knowing the range of providing creative abilities for the supreme administrative leaderships in a lot of tourist companies category (A) \& (B) in Egypt. Also knowing the impact of these abilities on the level and the content of the change processes and development that these organizations witnessed. Besides the study seeks the description of the organizational context characteristics prevailing in these organizations. 


\section{Aim of the study:-}

The current study aims at designing theoretical model, to describe the components and the impacts of development processes in travel agencies, as well as testing it practically upon a sample of companies.

This will be in addition of drawing a comparison between tourist companies' category (A) \& (B) concerning the modifiers and effects of development processes.

To achieve this aim, the current study seeks:

(1) The range of providing creative abilities for managers in tourist companies in Egypt.

(2) The effect of creative abilities of managers on the level of used organizational development.

(3) The effect of creative abilities of managers in the content of organizational development.

(4) The effect of organizational context characteristics in tourist companies on the level of organizational development.

(5) The effect of organizational context characteristics in tourist companies on the content of organizational development.

(6) The effect of the level of organizational development in the development content in tourist companies.

(7) The range of having differences between companies category (A) \& (B) concerning:- Creative abilities of the managers.

- Characteristics of organizational development prevailing in these companies.

- The level of organizational development used.

- The content of organizational development used. The importance of a study:-

It springs from some points:

First :- Theoretical aspect: 
The current study contributes on spotting light on the nature of the development processes in the tourist companies and knowing its components and effects. No drought that testing theoretical sample which describes the components and the effects of the organizational development in business environment of the tourist companies in Egypt, provides a basic of knowledge which is useful for the researchers in this field.

As well as it presents to the norms and change research and organizational development a different and distinguish environmental context on those which has been done in most of the former studies the Arab ones and the Western.

Second:- Practical aspect:

The current study contributes in providing an amount of knowledge, which may show up the behaviorism and organizational components of the organizational development processes in the Egyptian tourist companies it also provide a basic of knowledge and clarify its nature and content. Managers, administrative decisions makers, and change leaders can benefit from it in these companies.

This basic of knowledge can be useful for the decisions makers in designing and directing development and change processes which many of companies (A), (B) witness it the mean while aiming to increase their efficiency and realize their desired goals.

\section{Hypotheses of the study:}

Hypotheses of the current study can be divided according to the suggested theoretical model into four groups as the following:

First, hypotheses related to the impact of creative abilities of managers:

1- The more creative abilities and administrative

leadership the travel agencies have, the more probable 
carrying out the organizational change becomes. This change can include more than one level at the same time. This hypothesis include the following two sub- hypotheses: 1-1 The more creative abilities the managers have the more levels the organizational change can involve.

1-2 The more creative abilities the managers have, the more the organizational change handles both the aspects related to organizational designing and the other aspects, not subjected to it.

Second; the hypotheses subjected to the impact of organizational context:

2- The quality of the dimensions of the organizational context as the managers of the tourist company object of research affects so far précising the level and the content of the organizational development processes. That is how it is clarified in the following sub-hypotheses:-

2-1 The more the elements lessen in the quality of the organizational context; the more probable performing the organizational development at the company level as a whole. 2-2 The more the elements lessen in the quality of the organizational context; the more probable performing the organizational development at the group work level.

2-3 The more the elements lessen in the quality of the organizational context; the more probable performing the organizational development at the individual level.

2-4 The more the elements lessen in the quality of the organizational context; the more practicing the organizational development related to the organizational design.

2-5 The more the elements lessen in of the organizational context; the more practicing of the organizational development related to other fields than the organizational design. 
Third - The hypotheses related to the effect of the organizational change level:

3-There is an existence of a harmony between the change in the level and the change in the content in tourist companies; that appears in the following sub-hypotheses:

3-1 The more the targeted change was at the level of the company as a whole; the more this leads to a change in the aspects related to the organizational design.

3-2 The more the targeted change as at the level of the group work or at the individual level; this leads to a change in other aspects not related to the organizational design.

Fourth:- The hypotheses subjected to the difference between the large and small organizations:

4-The creative abilities for the managers in tourist companies category (A) , the organizational context in companies category (A) and the organizational change processes are more than companies category $(B)$. This is in the form (of sub-hypotheses) that comes here after:

4-1 It's expected that the creative ability (for the mangers) will increase in tourist companies category (A), more than these which are available for the managers in tourist companies category (B).

4-2 It is expected that the change in tourist companies category (A) will include more levels that these which the change in tourist companies category (B) includes.

4-3 It is expected that the change in tourist companies category (A) will include more contents that these which the change in companies category $(B)$ include.

4-4 It is expected that the variables of the organizational context and the work conditions in companies category (A) will be better than in companies category (B).

Theoretical model for study: 
Depending on the hypotheses that have been reached via surveying previous studies and more review of the organizational development, the current study is aiming to test five types of relations, which are:

1- The relation between the degree of having creative abilities for the managers and the organizational development level.

2- The relation between the degree of having creative abilities for the mangers and the organizational development content.

3- The relation between the quality of the elements of the organizational context and the organizational development level.

4- The relation between the quality of the elements of the organizational context and the organizational content.

5- The relation between the level of the organizational development and the organizational development content.

These relations can be expressed as in (Figure 1) which describes the suggested theoretical model for study.

Figure (1)

The suggested theoretical model for study 


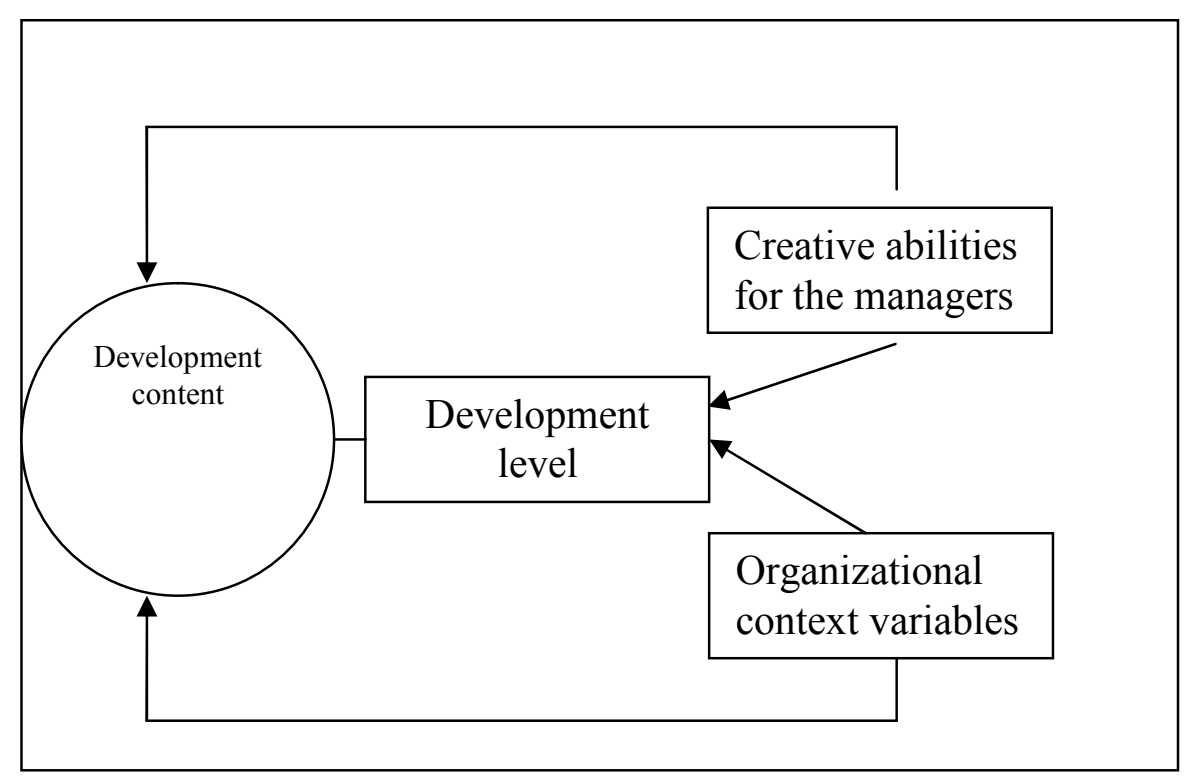

Variables of study and their measurements:

\section{First: Independent variables:}

We can classify independent variables in current study into two groups:

The first group includes variable describing creative abilities for managers and the second contains variables describing organizational context where they work in the tourist company.

- Independent Variables:

\section{1- Creative abilities for managers:}

This variable describes the range of available creative abilities for managers. The creative abilities are known to be the individual's ability to render new ideas not known before to deal with a certain problem, (Proctor, 1999).

\section{2- Variables of organizational context:}

This group includes the variable describing the internal environmental characteristics of the tourist companies in Egypt. It includes nine main variables: 
a- Aims: The clarity of the aims in the company and the range of accordance among the members of the company and to put it in priority.

b- Structure: the flexibility of the company organizational structure and the ability to achieve aims. Besides, depending on objective bases to classify work and the convenience of the internal design of the structure with work conditions and the nature of tasks desired.

c- Leadership: the range of re-enforcing the direct boss to the efforts done by the employee's and the style of the leadership used. Besides, the leaders ability to achieve goals and leading work teams effectively.

d- relations: the scope of harmony in work relations in the company and the cohesion of internal work groups. Also, the range of having a conflict and struggle among work teams in the organization.

e- Incentives: Opportunities of organizational development and progress available in a company as well as the justice in wages and incentives that can arouse enthusiasm and motivation for workers.

f- Work facilities: employers present ideas that help employees to achieve work activities. In addition, providing information needed for each one at work. Also, co-operation among different organizational units, rather than the range of having materialistic resources and needed potentional for practicing work activities.

g- Attitudes towards change: The general atmosphere in the organization regarding resisting change and development in the policy and procedure of work. In addition the orientation of higher administration towards on-going development and being re-enforced.

h- Communication: the ease and facility in conveying information between individuals and organizational units inside the company. How far do employers know about problems the 
employees face and having a teamwork spirit among employees in the company.

i- Decision making: This refers to how far the centralization of decisions in a company and the participation of lower organizational levels in decision making or providing desired information. This is added to the desire of the higher administration towards sharing in decision making.

- Organizational context variables have been estimated by using (Nadler \& Tushman's Scale, 1990) for organizational diagnosis after being translated into Arabic. Some additives are added to achieve wanted comprehensiveness to describe the dimensions of organizational context in the tourist company.

Tushman and Nadler's Scale Contained Seven dimensions only: Aims, structure, leadership, relations, incentives, work facilities and psycho - trends towards change.

\section{Second: the Medium Variable:}

The current study contains only one medium variable describing organizational change level. This variable describes three levels for organizational change:

- The individual level.

- The group level

- The company level as a whole.

- The current study (2002) relied on Musalams' scale aiming at knowing development activities practiced by tourist companies at these levels (fig. 3)

\section{Third: The Sub - Variable:}

The current study contains one sub-variable describing the content of organizational change processes in tourist companies.

This estimation depended on the list of change content presented by (Glick et al., 1990; 419)

He distinguished two kinds: 
(1) Design changes, which include fields, subjected to organizational structure and the responsibility of the higher administration. Also the ways of reaction between the company and external places. Change in coordination and internal communication is involved.

(2) Non - Design changes in other fields:

It is a whole change in the company or any related branch (unit). It is a change in strategies and policy at work. In addition those occupying the higher administrative positions in the company. They were noted in 10 items. The first 5 items describe changes in organizational design, and the other 5 items changes in other fields (Licart's scale was used. (fig. 4) entitle "the Experiments of change and development..

\section{- Community and sample of study:-}

It includes tourist companies class (A) and (B) which work in Greater Cairo

The sample of study has 56 tourist company, 27 class (B), 30 class (A). 4 companies were exempted and driven away for not completing all lists of questionnaire, so the final sample of study included 52 companies, 23 class (B) and 29 class (A)

\section{Methods of collecting data:}

The study depended on four types of questionnaire lists, which are:

1) Questionnaire list of the creative abilities this list has been directed to three of superior administrative leaders who are contributing in making change and development decisions in the company (in some cases two were in off) this category the available of the following positions: the director of the company, the administrative manager, the human resources manager, the development and research manager in some companies (if possible), 
2) The questionnaire list of the organizational context:

This list has been directed to three members if the category of the middle administration in each company (in some cases it was in off to have only two) this category includes the positions of director or head of department in the organizations scope of study.

(3) The questionnaire list change's level:

This list has been directed to the administrative manger or the human resources manager or the direct responsible of the organizational development processes in the company.

This is how a list was available in each company of the companies scope of study.

(4) The questionnaire list of change content:

This list has been directed as well to the administrative manager or the human resources manger or the direct responsible for the administrative development processes in tourist companies. This is how a list was also available in each company of the companies' scope of study.

\section{Methods of treating and data analysis:}

The current study depended on testing relations, which the suggested theoretical model contains a lot of methods of treating and data analysis with taking into consideration that the unit of analysis used in study is the company as a whole and this is as follows:

First: The qualitive statistic: Methods of the qualitive statistic have been used: the medium, the deviation standard, the minimum and the maximum for each variable of the study's variables. The purpose of this analysis is presenting a descriptive statistic for the study's variables. And also the correlation matrix has been calculated among all the study's variables aiming to make sure that there is no problem of Multicollinearity among the independent variables themselves. 
Second - The declination analysis : simple regression coefficient and multi declination coefficient have been calculated among many of the study's variables.

The simple regression coefficient had been calculated between the variable, which describes the creative abilities of the managers, and the variables that describe both level and content of the organizational development separately. The multi regression coefficient has been calculated between the variables that describe the organizational context from one hand, and the variables that describe both of the level land the content of organizational change from the other hand. Also, the multi regression coefficient been calculated between the levels and the content of the organizational development.

\section{Third : Test : T - Test}

This kind of test aims at knowing difference with statistical evidence in changes which describes companies. This is related to the creative abilities of managers, the level of development, organizational development content. There are three level $(0,10$, $0,05,0,01)$.

Fourth : Content analysis

Content analysis of responses has been done in the questionnaire list to classify the change attempts into: a change in organizational design and other fields. Besides, reaching limited dimension to describe the content of change processes in organization this has helped in illustrating a lot of result of quantities data.

\section{- Study outcomes:}

The outcomes of descriptive analysis of data and testing stable measuring. 
Table No. (1) Shows the results of the descriptive data analysis, including the medium values and the deviation coefficient for each variable in the study.

- Out of data descriptive analysis, the average of creative abilities of managers has reached $(82,81)$ degrees upon a scale consisting of (140) degrees. This means that creative abilities for sample items as a whole are higher than the average. This is considered a good indicator for the creative ability levels for the egyptian manager

And the correlation matrix shows between the study's variables diminution in the correlation coefficient among the independent variables altogether, the least correlation coefficient has reached $(0,004)$, and the highest correlation coefficient has reached $(0,797)$, this result refers to the existence of a big amount of independence between the independent variables and the inexistence for any problem for the Multicollinearity among these variables which give more trust in the results.

Table (2) shows Chronbach alpha results for the stability measurements to both creative abilities of the managers and organizational context.

The table shows the stability coefficient measurement of the creative abilities of the managers as it is considered a comprehensive measurement consisted of (45) items, and also the stability coefficient measurement of the organizational context after being divided in nine sub-dimensions which present it, in addition to the stability coefficients measurement for each dimension of the sub - dimensions separately and that is consisted of (5) items. 
Association of Arab Universities For Tourism and Hospitality, JAAUTH

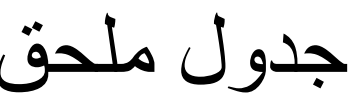


Table (2)

The results of Chronbach alpha for the measurements stability

The measurement

* Creative abilities of the managers

*Comprehensive organizational context

* Partly organizational context

* Sub-measurements for the

organizational context:

* Aims

* Structure

* Leadership

* Relations

* Incentives

* Facilities

* Psychological trends

* Communication

* Decisions making
Number of items

40

45

9
Coefficient stability alpha

0.5095

0.9671

0.9407 of

Table (2) shows the augmentation of the stability coefficients measurements in general. Alpha coefficient measurement for the comprehensive organizational context has reached $(0.96)$, as the same alpha coefficient measurement after being divided in nine sub-dimensions has reached about (0.94), and these stability coefficients are considered high relatively. And also the table shows the least stability coefficient for measurements of the suborganizational context that are consisted of five items (0.60), where as its highest coefficient $(0.86)$, they are considered as acceptable stability coefficients in the organizational studies. Although the alpha coefficient for the measurements of the creative abilities of the managers, didn't go so far $(0.50)$, which needed more analysis, so the researcher used the factor analysis methods to stand for the loading coefficients each item of the measurement items, this analysis showed the existence of (13) $\mathrm{sub}$ - factors that the measurement contains. By choosing the most loading items on each dimension it has been proved that we got (7) independent dimensions, their items and their loading coefficients are shown in table (3). 


\section{Table (3)}

Factor analysis results for the measurement items of the creative abilities of the managers

\begin{tabular}{llll}
\multicolumn{2}{c}{ Factor 1 } & \multicolumn{2}{c}{ Factor 2 } \\
Item & Loading & Item & Lading \\
& confinement & confinement \\
23 & 0.82 & 18 & 0.68 \\
1 & 0.76 & $\mathbf{3 4}$ & $\mathbf{0 . 4 8}$ \\
38 & $\mathbf{0 . 7 5}$ & $\mathbf{4 0}$ & $\mathbf{0 . 4 0}$ \\
35 & $\mathbf{0 . 7 4}$ & & \\
12 & -0.72 & & \\
26 & 0.63 & & \\
31 & 0.62 & & \\
22 & -0.61 & & \\
21 & 0.61 & & \\
24 & 0.59 & & \\
3 & -0.57 & & \\
27 & -0.56 & & \\
11 & 0.5 & & \\
13 & -0.55 & & \\
36 & 0.45 & & \\
9 & -0.49 & & \\
& & &
\end{tabular}

\begin{tabular}{|c|c|c|c|c|c|c|c|}
\hline \multirow{2}{*}{$\begin{array}{l}\text { Facto } \\
\text { Item } \\
8\end{array}$} & \multirow{2}{*}{$\begin{array}{l}\text { I } 3 \\
\text { Loading } \\
\text { confinement } \\
\mathbf{0 . 6 8}\end{array}$} & \multicolumn{2}{|c|}{ Factor 4} & & & \multicolumn{2}{|c|}{$\begin{array}{l}\text { Factor } 6 \\
\text { Item Loa }\end{array}$} \\
\hline & & 29 & $\mathbf{0 . 5 6}$ & 39 & $\mathbf{0 . 4 9}$ & 28 & \\
\hline 4 & 0.65 & 37 & -0.50 & 14 & -0.49 & 32 & -0. \\
\hline 20 & 0.48 & 17 & 0.14 & 10 & -0.45 & 2 & \\
\hline 7 & -0.38 & 25 & 0.39 & 5 & -0.34 & & \\
\hline 33 & 0.37 & 30 & 0.35 & & & & \\
\hline
\end{tabular}

As for not having a theoretical frame justifying the division of the creative abilities in to sub - factors, moreover the main aim of the current study is recognizing the relation between the creative abilities of the managers in general (without interfering in the content of these abilities) and the organizational development practices, it has been dependable on the measurement as it is in spite of the relative diminution of its stability coefficient.

\section{Study hypotheses test results:}

Depending on the suggested theoretical model in the study, the manipulation of the hypotheses has been done describing the probable relations between the independent variables: the creative abilities of the managers, organizational context, variable mean: the organizational development level, sub variable: organizational development content, as follows the (results of the) statistic data analysis and the test of the study hypotheses. 
First - The hypotheses related to the effect of the creative abilities for the managers:

Table (4) shows the results of the simple regression analysis for the effect of the variable for the managers creative abilities at the level of the organizational development used.

And it's clear that there is a direct relation with statistical evidence between the managers creative abilities and the organizational development practices at the individual level $(\mathrm{P}<$. $10)$ and also at the company level $(\mathrm{P}<.10)$, mean while the results showed the existence of inverse relation which doesn't have a statistical evidence between the managers creative abilities and the organizational development practices at the group level. The results refer to support the hypotheses 1-1:

The more creative abilities for the manger are increased; the organizational development will include more than one level for the change.

The results showed that the managers creative abilities are related directly to the organizational development practices at two different levels that are; the individual and the whole company

\section{Table No. (4)}

The effect of creative abilities for managers on the level of

Variable

Individual

level: stable

creative

abilities

Group level:

stable

Creative

abilities

Company level: organization development

Regression Standard $\mathbf{T}$

co-

efficient

(B)

4.633

0.062

$\begin{array}{lll}2.033 & 5.662 & 0.000\end{array}$

11.509

$-0.010$

12.227 error

2.019

0.024

2.294

2.612

0.026

0.012

(R2)

0.120 level
Evidence Limit $\epsilon$

0.024

0.662

0.440

0.004 


\section{$\begin{array}{llllll}\text { Creative } & 0.0593 & 0.049 & 4.049 & 0.056 & 0.071\end{array}$ abilities}

Table (5) shows the results of analyzing simple regression for the relation between having creative abilities of managers and the organizational development content.

\section{Table No. 5}

The effect of creative abilities for mangers on the level of organizational development.

Variable

Regression

Standard

$\mathbf{T}$

co-efficient error

The change in the (B)

1.003

2.568

0.012

2.561

0.989

creative

0.10

0.012

3.785 $-0.005$

abilities

In table (5) There is no relation of statistic evidence between the creative abilities for managers and the organizational development content. This result indicates that having creative abilities or not. This has no relation with change processes and development in the company.

The more the creative abilities increase, the organizational development can handle all aspects subjected to organizational design and other aspects in the company. There is no statistic evidence in this respect.

Second: hypotheses subjected to the effect of organization context:

By using the style of multi - regression for choosing the relation between the organizational context and development variable. A varied result has been proved (tables 8-7-6). These results of multi regression for the relation between the variables of organizational context and organizational development on the levels of the company, the group and the individual, as follows: 
Table No. 6

The effect of organizational context variables upon organizational development practices (the company)

Variable

Regression Standard $\mathbf{T}$ co-efficient error

Stable

Aims

9.917

Structure

Leadership

Relations

Incentives

Facilities

Attitudes

Communication

0.840

4.334

$-3.562$

$-0.987$

0.972

3.874

$-3.929$

Decision making

$-0.441$

1.977

$\mathrm{F}=1.513$
6.667

1.829

2.493

2.307

2.768

1.561

2.564

2.036

3.429

2.084

175

$$
\text { eviden }
$$

Evidence level

\section{(Table No. 7)}

The effect of organizational context variables upon organizational development practices (the group)

$\begin{array}{lcccr}\text { Variable } & \begin{array}{c}\text { Regression } \\ \text { co-efficient }\end{array} & \begin{array}{l}\text { Standard } \\ \text { error }\end{array} & \text { T } & \begin{array}{l}\text { Evidence } \\ \text { level }\end{array} \\ \text { Stable } & \mathbf{8 . 8 9 9} & \mathbf{3 . 3 3 1} & \mathbf{2 . 6 7 1} & \mathbf{0 . 0 1 1} \\ \text { Aims } & \mathbf{0 . 1 4 6} & \mathbf{0 . 9 1 4} & \mathbf{0 . 0 5 1} & \mathbf{0 . 9 5 9} \\ \text { Structure } & \mathbf{2 . 2 9 7} & \mathbf{1 . 2 4 6} & \mathbf{1 . 8 4 3} & \mathbf{0 . 0 7 2} \\ \text { Leadership } & \mathbf{0 . 1 9 7} & \mathbf{1 . 1 5 3} & \mathbf{0 . 1 7 0} & \mathbf{0 . 8 6 6} \\ \text { Relations } & \mathbf{- 0 . 7 2 0} & \mathbf{1 . 3 8 3} & \mathbf{- 0 . 5 2 1} & \mathbf{0 . 6 0 5} \\ \text { Incentives } & \mathbf{0 . 9 6 8} & \mathbf{0 . 8 2 5} & \mathbf{1 1 . 1 7 4} & \mathbf{0 . 2 4 7} \\ \text { Facilities } & \mathbf{- 1 . 3 2 2} & \mathbf{1 . 2 8 1} & \mathbf{- 1 . 0 3 2} & \mathbf{0 . 3 0 8} \\ \text { Attitudes } & \mathbf{- 0 . 3 4 2} & \mathbf{1 . 5 1 7} & \mathbf{- 0 . 2 2 6} & \mathbf{0 . 8 2 3} \\ \text { Communication } & \mathbf{0 . 2 8 3} & \mathbf{1 . 7 1 3} & \mathbf{0 . 1 6 5} & \mathbf{0 . 8 7 0} \\ \text { Decision making } & \mathbf{- 0 . 7 7 4} & \mathbf{1 . 0 4 1} & \mathbf{- 0 . 7 4 3} & \mathbf{0 . 4 6 1}\end{array}$

$\mathbf{F}=\mathbf{0 . 9 1 6}$ Evidence level $=\mathbf{0 . 9 1 6} \quad$ limit factor $=\mathbf{0 . 1 6 4}$ 
(Table No. 8)

The effect of organizational context variables upon organizational development practices (individual)

Variable

Stable

Aims

Structure

Leadership

Relations

Incentives

Facilities

Attitudes

Communication

Decision making

$\mathrm{F}=\mathbf{2 . 3 2 9}$
Regression co-efficient
Standard
error

1.512

1.857

$-0.616$

$-2.105$

0.029

$-0.743$

1.414

0.986
3.146

0.863

1.176

1.089

1.306

0.779

1.210

1.433

1.618

0.984
$\mathbf{T}$

2.053

1.752

1.579

$\mathbf{- 0 . 5 6 5}$

$-1.612$

0.037

$-0.641$

0.987

$\mathbf{- 0 . 6 1 0}$

0.636
Evidence level

It's clear from table (6) that the dysfunction in things related to the organizational structure was the only motivating factor to the organizational development at the company level as a whole ( $\mathrm{P}$ $<10$ ), other factors in the organizational context didn't have any effect with statistical evidence at this level. This result presents partly and limited support to the hypotheses 2-1: The more decreasing in the quality of the organizational context elements, the more probability in organizational development at the company level as a whole table (7) shows the same disorder in things related to the organizational structure was the only factor also motivating to the organizational development at the group level in the company $(\mathrm{p}<.10)$, but for other factors it seems that the disorder and the defect in the organizational structure and what following it from procedures and jobs description and others are the main (work) motive to the practices of the organizational development in companies scope of study. This result presents a limited and partly support to the hypothese 2-2: The more the quality of the elements of the organizational 
context the more probability in starting organizational development on the group.

Table (8) shows the unclearness of the goals of the company was the main factor précising the practices of the organizational development at the individual level.

Meanwhile there are many other factors such as psychological trends, communication and decisions making which didn't have the same evidential effect although they are more expected to be effective. This result shows the limited partly support, as well to the hypotheses 2-3: The more decreasing in the quality of the elements of the organizational context the more probability to start the organizational development on the individual.

Tables (9, and 10) show the analysis results for the multi regression of the relation between the variables of the organizational context and the content of the organizational development, if to development was related to the organizational design or to other fields in the company despite the organizational design prospectively.

\section{Table (9)}

Effect of organizational context variables on development content - development in organizational design.

$\begin{array}{lllll}\text { Variable } & \begin{array}{l}\text { Regression }(B) \\ \text { coefficient }\end{array} & \begin{array}{l}\text { Standard } \\ \text { error }\end{array} & \text { T } & \begin{array}{l}\text { Evidence } \\ \text { level }\end{array} \\ \text { Stable } & \mathbf{2 . 1 5 6} & \mathbf{1 . 5 1 7} & \mathbf{1 . 4 2 1} & \mathbf{0 . 1 6 3} \\ \text { Aims } & \mathbf{0 . 1 0 5} & \mathbf{0 . 4 1 6} & \mathbf{0 . 2 5 3} & \mathbf{0 . 8 0 2} \\ \text { Structure } & \mathbf{- 1 . 2 3 1} & \mathbf{0 . 5 6 7} & \mathbf{- 2 . 1 6 9} & \mathbf{0 . 0 3 6} \\ \text { Leadership } & \mathbf{0 . 3 2 4} & \mathbf{0 . 5 2 5} & \mathbf{0 . 6 1 6} & \mathbf{0 . 5 4 1} \\ \text { Relations } & \mathbf{- 1 . 1 5 3} & \mathbf{0 . 6 3 0} & \mathbf{- 1 . 8 3 0} & \mathbf{0 . 0 7 4} \\ \text { Incentives } & \mathbf{- 0 . 0 6 3} & \mathbf{0 . 3 7 6} & \mathbf{- 0 . 1 6 8} & \mathbf{0 . 8 6 7} \\ \text { Facilities } & \mathbf{0 . 4 9 1} & \mathbf{0 . 5 8 4} & \mathbf{0 . 8 4 1} & \mathbf{0 . 4 0 5} \\ \text { Trends } & \mathbf{1 . 4 6 9} & \mathbf{0 . 6 9 1} & \mathbf{2 . 1 2 6} & \mathbf{0 . 0 3 9} \\ \text { Communication } & \mathbf{0 . 5 3 5} & \mathbf{0 . 7 8 0} & \mathbf{0 . 6 8 6} & \mathbf{0 . 4 9 7} \\ \text { Decisions making } & \mathbf{- 0 . 0 2 7} & \mathbf{0 . 4 7 4} & \mathbf{- 0 . 0 5 8} & \mathbf{0 . 9 5 4}\end{array}$


$\mathrm{F}=1.949 \quad$ Evidence level $=0.071 \quad$ limit coefficient $=0.295$

Table (10)

Effect of organizational context variables on the development content - development in other fields.

$\begin{array}{lllll}\text { Variable } & \begin{array}{l}\text { Regression }(B) \\ \text { coefficient }\end{array} & \begin{array}{l}\text { Standard } \\ \text { error }\end{array} & \text { T } & \begin{array}{l}\text { Evidence } \\ \text { level }\end{array} \\ \text { Stable } & \mathbf{0 . 8 6 8} & \mathbf{1 . 6 6 0} & \mathbf{0 . 5 2 3} & \mathbf{0 . 6 0 4} \\ \text { Aims } & \mathbf{0 . 0 2 3} & \mathbf{0 . 4 5 6} & \mathbf{0 . 0 5 1} & \mathbf{0 . 9 5 9} \\ \text { Structure } & \mathbf{- 0 . 2 5 6} & \mathbf{0 . 6 2 1} & \mathbf{- 0 . 4 1 2} & \mathbf{0 . 6 8 2} \\ \text { Leadership } & \mathbf{- 0 . 4 6 0} & \mathbf{0 . 5 7 5} & \mathbf{- 0 . 8 0 0} & \mathbf{0 . 4 2 8} \\ \text { Relations } & \mathbf{- 0 . 0 9 7 5} & \mathbf{0 . 6 8 9} & \mathbf{- 0 . 1 4 1} & \mathbf{0 . 8 8 8} \\ \text { Incentives } & \mathbf{- 0 . 1 6 5} & \mathbf{0 . 4 1 1} & \mathbf{- 0 . 4 0 1} & \mathbf{0 . 6 9 1} \\ \text { Facilities } & \mathbf{0 . 7 4 0} & \mathbf{0 . 6 3 9} & \mathbf{1 . 1 5 8} & \mathbf{0 . 2 5 3} \\ \text { Trends } & \mathbf{1 . 2 2 2} & \mathbf{0 . 7 5 6} & \mathbf{1 . 6 1 6} & \mathbf{0 . 1 1 4} \\ \text { Communication } & \mathbf{- 0 . 3 7 5} & \mathbf{0 . 8 5 4} & \mathbf{- 0 . 4 3 9} & \mathbf{0 . 6 6 3} \\ \text { Decisions making } & \mathbf{0 . 1 2 9} & \mathbf{0 . 5 1 9} & \mathbf{0 . 2 4 8} & \mathbf{0 . 8 0 5}\end{array}$

$\mathrm{F}=0.650 \quad$ Evidence level $=0.748 \quad$ limit coefficient $=0.122$

It's clear from table (9) the defect in the factors related to both structure and work relations, in addition to the existence of negative psychological trends for the company employees, these were the most important organizational context variables that leaded to develop all the subjects related to the organizational design such as the restructure and changing the ways of communication and the interaction in the organization.

These results show the support the hypothese 2-4: The more we decrease the quality of the elements of the organizational context, to organizational development practices that are related to the organizational design will increase.

And on the contrary of the previous results, table (10) shows the non existence of a relation with statistical evidence between the dimensions of the organizational context and the development practices that are related to other fields than the organizational design. And these results don't support clearly the hypotheses 2-5: 
The more we decrease the quality of the elements of the organizational context, the organizational development practices that are related to other fields than the organizational design. Apparently that the change processes in the company strategies and policies and superior leaderships are controlled by other considerations that the quality of the organizational context.

Third - The hypotheses related to the organizational development level:

Table (11) and table (12) show the analysis results of the multi regression between the level of practicing the organizational development (individual, group, company) and the development attempts related to the company design and those are related to other fields successively.

\section{Table (11)}

The effect of the organizational development level in the development content - development in the organizational design.

$\begin{array}{ccccc}\text { Variable } & \begin{array}{c}\text { Regression } \\ \text { coefficient (B) }\end{array} & \begin{array}{c}\text { Standard } \\ \text { error }\end{array} & \begin{array}{c}\text { T } \\ \text { Evidence } \\ \text { Stable }\end{array} \mathbf{2 . 3 6 4}^{\text {level }} \\ \text { company level } & \mathbf{0 . 0 5 1} & \mathbf{0 . 6 8 6} & \mathbf{3 . 4 4 5} & \mathbf{0 . 0 0 1} \\ \text { F.032 } & \mathbf{1 . 5 9 1} & \mathbf{0 . 1 1 8}\end{array}$

$\mathrm{F}=2.532 \quad$ evidence level 0.118 limit coefficient $=0.048$

It's clear from table (11) that the relations with statistical evidence don't exist between the organizational development at the company level and (practices of development of) the internal design for the company.

This results shows that there is no support to the hypothese 3-1:

If the targeted change is at the level of the company as a whole, this will lead to the change of the aspects related to the organizational design.

\section{Table (12)}

The effect of the organizational development level on the development content - development in other fields

$\begin{array}{lllll}\text { Variable } & \begin{array}{l}\text { Regression } \\ \text { (B) coefficient }\end{array} & \begin{array}{l}\text { Standard } \\ \text { error }\end{array} & \text { T } & \begin{array}{l}\text { Evidence } \\ \text { level }\end{array}\end{array}$


Stable 3.085

0.834

3.697

0.001

Individual level

0.105

0.070

1.498

0.141

Group level

$\mathbf{- 0 . 0 7 0}$

0.074

$-\mathbf{0 . 9 5 1}$

0.347

$\mathrm{F}=1.190$

Evidence level $=0.313$

limit

coefficient $=0.046$

And the same thing in table (12) the results show that the relations with statistical evidence don't exist between the organizational development at the group level or at the individual level and the organizational development practices related to other fields in the company. And this result doesn't support the hypothese 3-2: as long as the targeted change at the group level or individual level this leads to the change in other fields not related to the organizational design.

Fourth - Hypotheses related to the differences between the tourist companies category (A), (B) and private organizations:

Table (13) shows the results of T-test for the difference between the media which describe the creative abilities for managers in companies category (A) and (B).

\section{Table (13)}

Results of T-test for the differences between the media of creative abilities of the managers.

$\begin{array}{llll}\text { Variable Medium } & \begin{array}{l}\text { Standard } \\ \text { deviation }\end{array} & T & \begin{array}{l}\text { Evidence } \\ \text { level }\end{array}\end{array}$

Companies

category (B)

Companies

category (A)

It's notable that in table (13) there were differences with statistical evidence between the media of the companies category (A) and (B) related to the creative abilities of the mangers.

The medium of creative abilities has risen in tourist companies category (A) more than tourist companies category (B) with one 
spiritual degree $(\mathrm{p}<.0 .1)$, the medium creative abilities of the mangers in companies category (A) has reached about (90) degrees on the scale with a maximum of (140) degree, where as it doesn't exceed more than (73.5) for the managers in companies category (B).

This result shows clearly the support of the hypothese 4-1: It's expected that the creative abilities of the managers will increase in companies category (A) more than which are available for the managers in companies category (B).

Table (14) shows T-test results between the media which describe the level of the organizational development used in companies category (A) or (B).

\section{Table (14)}

T-test results for the difference between the media of the development level used

$\begin{array}{ccccccc}\text { Variable } & \begin{array}{c}\text { Arithm } \\ \text { etical } \\ \text { medium }\end{array} & \begin{array}{c}\text { Standard } \\ \text { deviation }\end{array} & \text { T } \begin{array}{c}\text { Evidenc } \\ \text { e level }\end{array} & \text { F } & \begin{array}{c}\text { Evidence } \\ \text { level }\end{array}\end{array}$

Individual

level:

Companies $\quad 7.739 \quad 1.763$

Category

Companies

$11.414 \quad 3.257$

$-4.8680 .000$

$15.04 \quad 0.000$

Category

(A)

Group level

:

Companies $\quad \mathbf{1 0 . 4 7 8} \quad 2.643$

Category

(B)

$10.758 \quad 3.419$

$-0.3240 .740$

2.78

0.101

Companies

Category

(A)

Organizati

on level: 
Companies $\quad 16.565 \quad 4.009$

Category

(B)

22.937

6.715

$-4.0140 .000$

9.566

0.003

Companies

Category

(A)

Results in table (14) show the differences with statistical evidence between the media of tourist companies category (A) and companies category (B) which are related to the level of the development used. Companies category(A) showed media to use the three levels of development (individual, group, and company) that are higher than companies category $(\mathrm{B})$. differences in media with statistical evidence were for each individual level $(\mathrm{P}<.01)$ and the whole company's level $(\mathrm{P}<.01)$. results have shown that the medium expressing degree for the organizational development practices at the individual level, reached (11.4) in companies category $(\mathrm{A})$ and that is higher than the companies category $(\mathrm{B})$ which reached (7.7) only.

Also the medium expressive degree for the organizational development practices reached at the level of the whole company in companies category (A) (22.9) degree, but it laid down at (16.56) degree as a medium in companies category (B). This is proved to be an increase in the organizational development rate at the level of the whole company in companies category (A) notably.

Compared with companies category (B). as for the practices related to the organizational development of the group level. Ttest didn't show the existence of differences with statistical evidence between the media of companies (B) and companies (A). the total results of T-test show the support of the hypothese 4-2: It's expected that the change (in tourist companies category (A) will include levels more than those which the change in tourist companies category (B) includes. 
Table (15) shows T-test results for the differences between the media that describe the content of the organizational development used in tourist companies category (A), (B)

Table (15)

T-test results for the difference between the media of tourist companies category (A), (B) related to the content of the organizational development.

Variable

$\begin{array}{lll}\begin{array}{l}\text { Arithm } \\ \text { etical }\end{array} & \begin{array}{l}\text { Standar } \\ \text { d }\end{array} & \mathbf{T} \\ \text { medium } & \text { deviatio } & \\ & \mathbf{n} & \end{array}$

Organizational design:

Category (B)

Companies

Category (A)

Other fields :

Companies category $(\mathrm{B})$

Companies category(A)

\subsection{1}

3.310

3.304

3.413

Evide F
nce
level

Evidenc e level

Results in table (15) show that there are no differences with statistical evidence among the media of companies' category (B), (A) related to the content of the development it seems to be that the practices of the organizational development in general are not restricted to the type of the organization.

We conclude that there is no support for the hypotheses 4-3: It is expected that the change in companies (A) will include more contents that those involved in the change of companies (B).

Finally, table (16) show the T-test results for the differences between the media which describe the quality of the elements of the organizational context in tourist companies (A) and tourist companies (B) 
Table (16)

T-test results for the differences between the media of the companies (A), (B) concerning the quality of the elements of the organizational context

Variable

Aims:

Companies (B)

Companies (A)

Structure :

Companies (B)

Companies (A)

Leadership:

Companies (B)

Companies (A)

Relations:

Companies (B)

Companies (A)

Incentives:

Companies (B)

Companies (A)

Facilities:

Companies (B)

Companies (A)

Trends:

Companies (B)

Companies (A)

Communication :

Companies (B)

Companies (A)

Decisions making :

Companies (B)

Companies (A)
Arithmetical Standard T

medium deviation
Evidence F level
Evidence level

$\begin{array}{lllllll}3.449 & 0.750 & - & & & \\ 4.286 & 0.864 & 3.673 & 0.001 & 0.429 & 0.515 \\ & & & & & \\ 3.238 & 0.832 & - & & & \\ 3.336 & 0.716 & 0.456 & 0.61 & 0.156 & 0.694 \\ & & & & & \\ 3.570 & 0.791 & & & & \\ 3.360 & 0.743 & 0.987 & 0.328 & 0.022 & 0.883 \\ 3.708 & 0.650 & & & & \\ 3.703 & 0.578 & 0.031 & 0.967 & 0.074 & 0.786 \\ & & & & & \\ 3.166 & 0.652 & - & & & \\ 3.970 & 0.867 & 3.688 & 0.001 & 2.874 & 0.096 \\ 3.401 & 0.693 & - & & & \\ 3.429 & 0.784 & 0.133 & 0.895 & 0.595 & 0.444 \\ \end{array}$

$\begin{array}{ll}3.342 & 0.418 \\ 3.316 & 0.606\end{array}$

0.1750 .862

$4.337 \quad 0.042$

3.378

0.607

3.385

0.759

$0.036 \quad 0.972$

1.6990 .198

\subsection{7}

0.763

3.973

0.819

3.4060 .001

0.9150 .343

Table (16) shows three elements only for the organizational context. There are differences with statistical evidence between the media of tourist companies' category "B" and "A" they are specifically: aims $(\mathrm{P}<.01)$, incentives $(\mathrm{P}<.01)$ and decision- 
making $(\mathrm{P}<.01)$. There has been a notable improvement in the quality of these elements in companies "A" and "B". The rest of the elements of organizational context have no essential differences between the two categories. These results indicate the partial agreement for the hypothesis 4-4: (It is expected for the organizational context variables and work conditions in "A" to be better than "B":

\section{- The analysis for the study descriptive data content:}

This analysis shows the existence of a lot of development fields the organizations have witnessed:

- Adding or omitting some administrative units in the framework of re-structure, a lot of companies "a", "B" have witnessed. This was in cope with redistributing authorities and validities among different administrations. There is a desire for increasing decentralization.

- Application of modern technology in the field of manufacture in companies "A" and using digital registering.

- Sharing in strategic alliances with some large companies, local and regional for making use of common potential in facing challenges and international competition.

- Constructing new incentive systems and developing those of human resources administration besides making investigations to know the needs and wishes of employees, with the aim of providing more stable work environment.

- A total restructure for one of the groups of special companies has taken place, with re-distributing responsibilities and authorities. In addition, muddying the tasks and work activities and reducing employment in some administrative and clerk jobs. Besides, modifying nomination for some organizational units.

- Carrying out large marketing studies and constructing rules of electronic data for clients, aiming at improving the 
service rendered to them for keeping up the competitive centre for the company in the market.

- Constructing electronic sites for some companies on the internet to increase reaction with clients. Also, transmitting and updating the information they need.

In addition, facilitating rendering necessary services as well as the electronic link among different organizational units through the internet.

- The tendency of some companies to apply the connotation of an organization without papers or electronic government.

- Condensing the programs of raising skills and necessary abilities for the employees in the companies.

\section{Conclusion and recommendations:}

Out of discussing results, we can reach a lot of extracts as follows:

- The creative abilities of managers in general, are considered to be higher than the average. This means that, there is still possibility to elevate and improve this kind of abilities through condensing training programs designed for this purpose, especially those directed to managers in tourist companies "B" without creative abilities of managers as well as changing the traditional thinking style, the attempts of development for tourist companies in Egypt will not succeed.

- Relating the managers' creative abilities to practicing organizational development at the individuals' level and the company as well. Most administrative and development programs on the individual level such as:

The program of elevating individual abilities and skills as well as planning organizational track. Also, on the level of the company like: total quality management (TQM), business process reengineering (BPR), enterprise resource planning (ERP), etc. 
Administrative leadership marked by innovation is always needed. It should have the spirit of creativity. This will help in starting development processes in the organizations, mobilizing and keeping up for continuity.

- Having no relation with statistical evidence between creative abilities and the content of organizational development that refers to providing creative abilities for managers. This can be a necessary condition to start and mobilize development process. That can not affect directly later on in the content of these processes.

- The internal environment of organization has showed a little effect than expected in the levels of development processes.

Using the descriptive organizational scale has led to personifying the fields of weakness in the dimensions of organizational in companies. The disorder in organizational structure was the main factor that determined the attempts of development at the level of both the company and the work group. Where as, the ambiguity of aims was the main motive for development processes on the individual level. It seems that organizational structure is the real mirror for the quality of internal environment in a company.

- Developing processes in organizational design have been affected by the dimensions of organizational context subjected to both the organizational structure, work relations and psycho - attitudes for workers towards change.

If there is a disorder in organizational structures, with having no quality work relations, this will lead to carrying to development processes in the affairs related to the company design and restructuring. Where as development in other fields. There seems 
to be other external factors that motivate development process in these fields.

- The relative rise for the creative ability medium of managers in tourist companies "A", rather than "B", refers to the internal work conditions and environment that have an effect on providing this type of abilities for managers.

- The perocratic trend dominating in companies "B" will lead to delaying some of the managers' abilities. Besides, the environment of varied works and competition conditions among conditions can make managers more able to create and innovate. Moreover, the relative flexibility in choosing and appointing managers in companies "A" may make these companies more able to polarize managers more creative and innovative.

- Practicing organizational development in the companies "A" are more comprehensive than those dominating in "B". Companies "A" have proved a relative rise in the rates of carrying out development processes at the level of the individual, the group and the company as a whole, compared to companies "B". The freedom of moving and the desire in adaptation with environmental changes, make the development processes in companies "A", more total than those in "B". Despite having no differences between them in the content of developing processes.

- Companies' category (A) showed a noticeable improvement in values of the variables expressing aims of the company. Work aims may be in companies' category (A) (as it is often considered the profit) more clear than work aims in companies' category (B) that may not be the same clear. Some may think this is to follow the rules and regulations of the work, others think this is how to give a good service to the beneficiaries, and some other think this 
is to keep the government financial safe and decrease the costs .....etc.

- They showed also the incentives system in tourist companies category $(\mathrm{A})$ is better than the one prevailing in companies category (B), as the companies category (A) are more able to reward their employees, as well as their managers have more space of freedom in rewarding those who have high performance, in contrast with the companies category (B), as the direct boss is not capable of rewarding his subordination, according to the rules and the regulations of the rewards that are controlled by considerations different from the superior manager evaluation.

- In the same manner, due to the prevailing centralization in tourist companies' category (B), managers often feel it especially in the lower levels, that they don't have real authorities in making decisions, which has negative effect on their psychological attitudes towards the prevailing types of making decisions.

But in companies category (A), manages often fell more freedom in making decisions due to their direct attachment with the market power, and their knowledge for the competition circumstances. As well as the speed and the quality of the customer service that are required in companies category (A) which give them more space of power and authority in making decisions without getting back to their superiors, and turn their psychological attitudes toward the positive types of making decisions more than those in tourist companies category (B).

Relying on the previous conclusions, the study recommends the following:

- It is necessary growing and developing the creative abilities for the managers early, before taking over administrative positions, and focusing on improving their 
creative thinking skills and their analysis thinking, and providing the appropriate environment for practicing them.

- The importance of developing their positive psychological trends toward the change for the employees working in tourist companies due to its necessity to push and motivate the attempts of the organizational development. The absence of these attitudes may lead to the failure of the bet plans and the strongest development programmes and increase the possibility of its resistance and not responding to them or adapting with them.

- Supporting the idea of turning toward the consumer (customer) in tourist companies because he is the basic of all the change and development attempts even in the tourist institutions and abandoning the concept of "beneficing" in dealing with the receptive of these institutions services.

- Strengthen the concept of quality in the superior administrative leadership minds in tourist companies to enable them to compete locally and internationally. To be convinced of this concept, this often leads the mangers to do more attempts in developing and improving continuously in the processes and administrative systems.

- The organizational development attempt should be followed by a change in the prevailing organizational culture so that the development will be a life style, and not just a task will be left after finishing it.

- We have to admit that the attempts of the organizational development could be exposed to the failure even in the most developed countries and the keenest on the success. There for they have to recognize exactly the reasons of the failure and avoid them and not to feel tranquility for the limited short-term success. May be the early success for a development program is one of the causative factors of the failure later. 
- We must admit that the development efforts are considered from the long term investments, and the company will not collect its outcome in the short term. Superior administration in companies should give the continuous support for these kinds of efforts with patience on realizing the hoped results without any rashness to reach the results, so that these efforts wouldn't fail in the first stages of their exertion.

أولا المراجع العربية: - أبية

ـ أبو إدريس محمد العزازي( 2002 )" اتجاهات القيادات الإدارية نحو امكانية تطبيق مداخل تطوير المنظمات والأداء في البيئة المصرية.

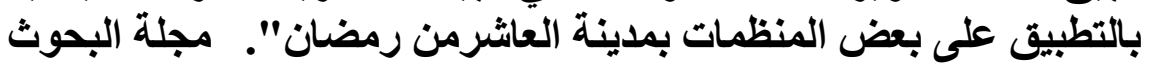

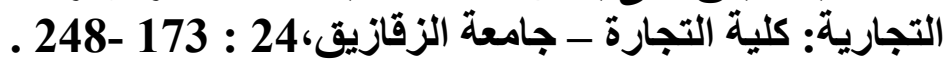

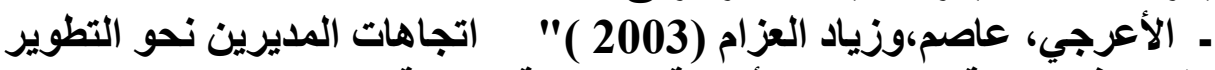

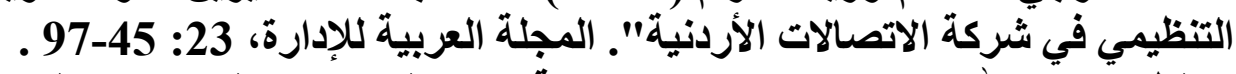

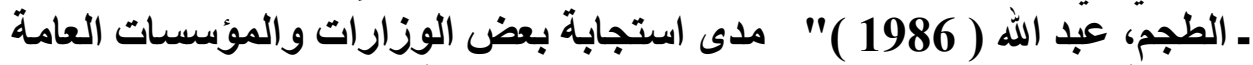
السعودية لعوامل التغيير ". مركز النشر العلمي، جامعة الملثك عبد العزيز:جداهد.

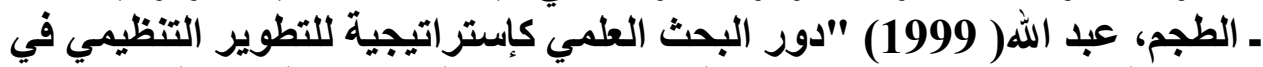

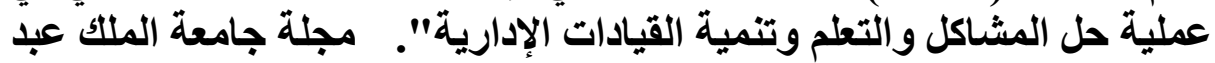

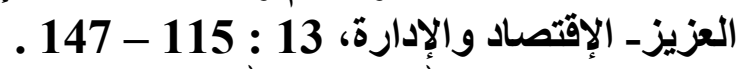

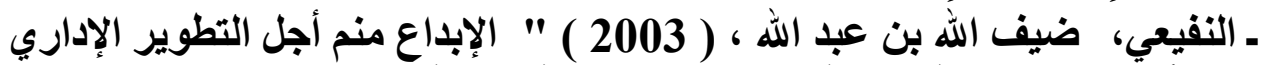
في الأجهزة الحكومية بمدينة الرياض ". مجلة جامعة الملك عبد العزيز - الإقتصاد الإداد

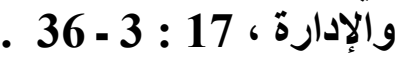
ـ حمور ، ميرغني عبد العال ( 1987 ـ 1987 ) "التطوير الإداري والخصوصية العربية". المنظمة العربية للعلوم الإدارية: عمان (

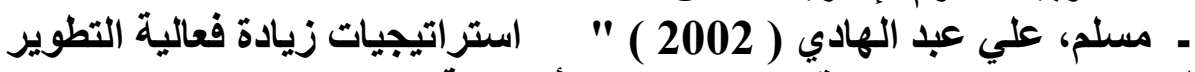
التظظيمي". مشروع بحث رقم 1998 / 1988 أكاديمية البحث العلمي والتكنولوجيا.

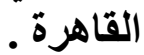
ـ هندي ، وحيد ( 2001 ) " تطوير المنظمات: تلخلات علم السلوك لتحسين

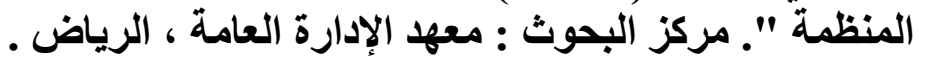




\section{Second - The foreign references:}

- Aims, J., Slack, T., and Hinings, C. (2002). "Values and organizational change". The Journal of Applied Behavioral Science, 38: 436-465.

- Armenakis, A. and Bedeian, A. (1999). "Organizational change: A review of theory and research in the 1990s". Journal of Management, 25: 293-315.

- Casile, M. and Davis - Blake (2002). "When accreditation standards change: Factors affecting differential responsiveness of public and private organizations". Academy of management Journal, 45: 180-195.

- Coghlan, D. (1994). "Research as a process of change: Action science in organizations". Irish Business and Administrative Research, 15: 119-135.

- Dacin, M., Goodstein, J., and Scott, W. (2002). "Institutional theory and Institutional change: Introduction to the special research forum". Academy of Management Journal, 45: 4557.

- Daft, R. (2003) Organization Theory and Design. ( $8^{\text {th }}$ ed.), South - Western, Mason, OH.

- Damanpour, F. (1991). "Organizational innovation: A meta analysis of the effect of determinants and moderators. "Academy of management Journal, 34: 555-590.

- Dutton, J., Ashford, S., O'Neill, R., and Lawrence, K. (2001). "Moves that matter: Issue selling an organizational change". Academy of Management Journal, 44: 716-737.

- Elden, M., and Chisholm, R. (1993). "Emerging varieties of action research: Introduction to the special issue". Human Relations. 46: 121-142.

- Field, R., and House, R. (1995). Human Behavior in organizations: A Canadian Perspective. Prentice Hall Canada Inc., Scarborough, Ontario. 
- French, W., and Bell, C., (1995). Human Behavior in organizations: A Canadian Perspective. Prentice Hall Canada Inc., Scarborough, Ontario.

- French, W., and Bell, C., (1995). Organization Development: Behavioral Science Interventions for organization Improvement. Prentice - Hall, Inc. Upper Saddle River, N.J.

- Frohman, A. (1997). "Igniting organizational change from below: The power of personal initiative". "Organizational Dynamics. Winter: 39-53.

- Glick, W., Huber, G., Miller, C., Doty, D., and Sutcliffe, K. (1990). "Studying changes in organizational design and effectiveness: Retrospective event histories and periodic assessments". Organization Science, 1: 293-312.

- Grant, d., Wailes, N., Michelson, G., Brewer, A., and Hall, R. (2002). "Rethinking organizational change". Strategic Change, 11:237-242.

- Gresov, C. Haveman, H., and Oliva, T. (1993). "Organizational design, inertia, and the dynamics of competitive response". Organization Science, 4: 181-208.

- Hall, R. (2002). "Enterprise resource planning systems and organizational change: transforming work organization? "Strategic Change, 11: 263-270.

- Haveman, H., (1992). "Between a rock and a hard place: organizational and performance under conditions of fundamental environmental transformation. Administrative science quarterly, 37: 48-75.

- Kelly, D., and Amburgey, T. (1991). "Organizational inertia and momentum: A dynamic model of strategic change". Academy of Management Journal, 34: 591-612.

- Kotter, J. (1994). "Why transformation efforts fail". Harvard Business Review, 6: 1-15.

- Kotter, J. (1996). Leading Change. Harvard Business School Press, Boston, MA. 
- Kraatz, M. and Moor, J. (2002). "Executive migration and institutional change". Academy of Management Journal, 45: 120-143.

- Latham, G. (2003). "Goal setting: A five - step approach to behavior change". Organization Dynamics, 23: 309-318.

- Lewin, K. (1946). "Action research and minority problems". Journal of Social Issues, 2: 34-46.

- Lovelace, K., Shapiro, D., and Weingart, L. (2001). "Maximizing cross - functional new product teams innovativeness and constraint adherence: A conflict communications perspective". Academy of management Journal, 44: 779-794.

- Meyer, A., and Goes, J. (1988). "Organizational Assimilation of innovations: a multilevel contextual analysis". Academy of Management Journal, 31: 897-923.

- Meyer, A., Brooks, G., and Goes, J. (1990). "Environmental jolts and industry revolutions: Organizational responses to discontinues change". Strategic Management Journal, 11: 93110.

- Nadler, D., and Tushman, M. (1990). "Beyond the charismatic leader: Leadership and organizational change". California Management Review, 32: 77-97.

- Nolan, R., and Croson, D. (1995). Creative Destruction: A six - stage process for transforming the organization. Boston, MA: Harvard Business Cool Press.

- Okhuysen, G. (2001). "Structuring change: Familiarity and formal interventions in problem - solving groups". Academy of Management Journal, 44: 794-809.

- Palmer, I., and Dunford, R. (2002). "Who says change can be managed? Positions, perspectives and problematic". Strategic Change, 11: 243-251.

- Pasmore, W., and Fagans, M. (1992). "Participation, individual development and organizational change: A review and synthesis". Journal of Management, 375-397. 
- Peters, T. (1990). "Get innovate or get dead: Part 1". California Management Review, 32: 9-26.

- Pettigrew, A., Woodman, R., Cameron, K. (2001). "Studying organizational change and development: Challenges for future research". Academy of management Journal, 44: 697-714.

- Poole, M., Van de Ven, A., Dooley, K. and Holemes, M. (2000). Organizational change and Innovation Processes: Theory and methods fro research. New York: Oxford University Press.

- Rajagopalan, N., Spreitzer, G. (1997). "Toward a theory of strategic change: A multi - lens perspective and integrative framework". Academy of Management Review, 22: 48-80.

- Robbins, S. (2001). Organizational Behavior. (9 $9^{\text {th }}$ ed.), Prentice Hall, Upper Saddle River, N.J.

- Robertson, P., Roberts, D., and Porras., J. (1993). "Dynamics of planned organizational change: Assessing empirical support for a theoretical model". Academy of Management Journal, 36: 619-635.

- Sashkin, M., and Burke, W. (1987). "Organization development in the nineteen - eighties". Journal of Management, 13: 393-417.

- Sastry, M. (1997). "Problems and paradoxes in a model of punctuated organizational change". Administrative Science Quarterly, 42: 237-275.

- Siegal, W., Church, A., and Javitch, M., et al. (1996). "Understanding the management of change: An overview of managers perspectives and assumptions in the 1990s". Journal of organizational change management, 9: 54-80.

- Stewart, E. (1991). "Rate your readiness to change". Fortune, Feb. : 106-110

- Tsoukas, H., and Chia, R. (2002). "On organizational becoming: Rethinking organizational change". Organization Science, 13: 567-582. 
- Van de Ven, A. and Huber, G. (1990). "Longitudinal field research methods for studying processes of organizational change". Organization Science, 1: 213-219.

- Van de Ven, A., and Poole, M. (1995). "Explaining development and change in organizations". Academy of Management Review, 20: 510-541.

- Wong - MingJi, D. and Millette, W., (2002). "Dealing with the dynamic due of innovation and inertia: The in - theory of organization change". Organization Development Journal, 20: 36-52.

- Woodman, R. (1989). "Organization change and development: New arenas for inquiry and action". Journal of Management, 15: 205-228.

- Wright, C., and Kitay, J. (2002). "But does it work? Perceptions of the impact of management consulting". Strategic Change, 11: 271-278. 


\section{Appendix (1) \\ Creative abilities scale}

The following is a number of statement that describe persons behaviors and attitudes in tourist companies. You are asked to agree or disagree on each statement.

Put a $(\checkmark)$ below the degree that express your opinion.

\section{Statement}

1- I am often sure to follow the right procedures to solve the problems.

2- It's a waste of time to ask questions without having a hope to get an answer

3- I concentrate strongly on what I am interested in more than what other people are doing.

4- I believe that following the method step by step is the best way to solve the problems. 5- In group meeting I sometimes declare opinions that make other people angry.

6- I spend a lot of time thinking what other people think of me

7- It's important to do what $I$ believe is right instead of trying to have others support

8- Members who seem to be not sure of their information do not get my respect.

9- I desire a lot of exciting and enjoyable things more than others.

10- I know how to make sure from the truth of may internal impressions.

11- I am able to deal with the difficult problems for a long time.

12- Sometimes, I have this strong feeling of desiring a change.

13- My best ideas often come to me when I am relaxing.

14- I depend on my since for the right tan the wrong when I am solving problems.

15- In solving problems I do the problem analysis quickly.
Agre Neutral Disagre

e

e 
16- Sometimes, I have not to follow the rules.

17- I like hobbies that depend on collecting things.

18- Day dreams are the motivating powers for my important projects.

19- I like reasonable and objectives persons.

20- As jobs preference, I like to be a doctor and not a discovered.

21- I deal smoothly with people belonging to my job category.

22- I have a great sense of beauty.

23- I am aiming to achieve a better place and more influences in life.

24- I like members who have confidence.

25- Ambition has no relation with success in solving problems

26- In a discussion, I am happy to find someone who disagrees with me without losing our friendly feeling.

27- I'd rather prefer reaching new ideas than convincing the other with them.

28- I feel happy to stay a whole day a lone thinking of may memories.

29- I prefer to avoid the situations which make me feel les than the others.

30- In evaluating things, the source is more important than the context.

31- I feel worry about uncertain things.

32- I like members following the rules.

33- Self respect is more important for me than respecting the others.

34- Members who are trying to achieve the perfection are unwise.

35- I rather prefer working with others than working alone.

36- I prefer the kind of work which allows me to influence on others.

37- Problems which I am facing in my life don't have perfect solutions. 
38- I like to have a place for every thing and to have every thing in its place.

39- Speakers who use strange words want to show them selves.

40- I am often described by the others that I have a great ability to create. 


$$
\text { " اثز القدرات الإبداعية والمسار التنظيمي }
$$

\section{للمديرين علمى تطوير الثركات السباحبة في مصر"}

- تهدف هذه الاراسة إلى بناء نموذج يصف محددات وآثار عمليات التطوير وأختبـارة

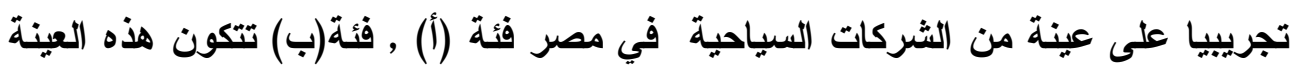
من (52) شركة سياحية. - كما تهدف هذه الاراسة إلى إجراء مقارنة بين الثركات السياحية فئة (أ) والثركات

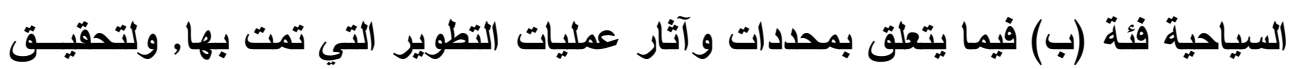
هذا الهـف تسعى الاراسة إلى التعرف على مدى توافر القدرات الإبداعية لاى مــديري هذة الثركات وأثر هذة القدرات في مستوى التطوير التظيمي المستخدم وأيضا أثر هذه الته

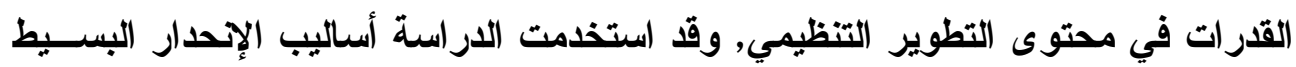
والإحدار المتعدد واختبارات t- test بغرض إختبار فروض الدورئ

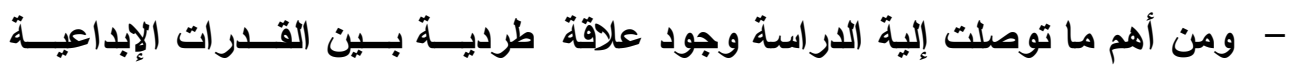
للمديرين وممارسات التظوير التظظيمي , وعدم وجود علاقة بــين القـــــات الإبداعيــة للمديرين ومحتوى التطوير التنظيمي • وجلت الدراسة أيضا أن الخلل في الهيكل التظيمي كان هو العامل الوحيد المحرك للقيام بالتظوير التظيمي على مستوى الثركات ككل وكذلك على مستوى جماعة العمل , كمــا

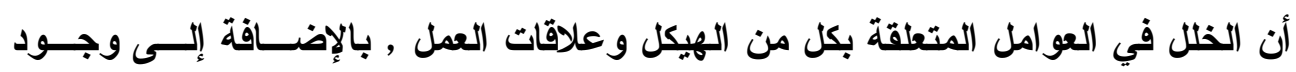

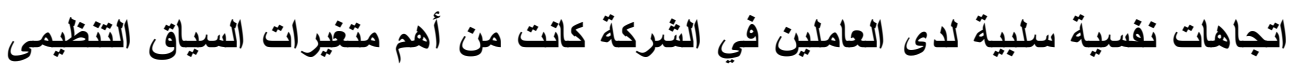
التى أدت إلى إجراء تطوير في الثركات مثل إعادة الهيكلة وتغييـر أســاليب الاتصـــال و التفاعل فى الثركة وأخيرا توصلت الدراسة إلى إرتفاع متوسط القدرات الإبداعية في الشركات السياحية فئة(أ) عنة فى الشركات السياحية فئة(ب) كما وجدت توفئ تحسناً ملحوظاً

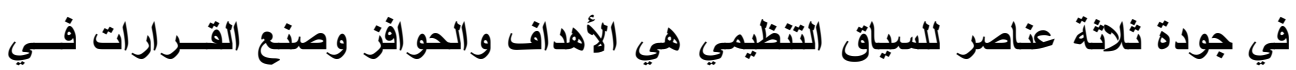

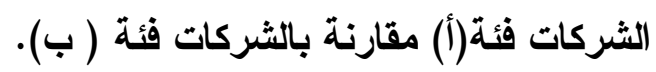

